
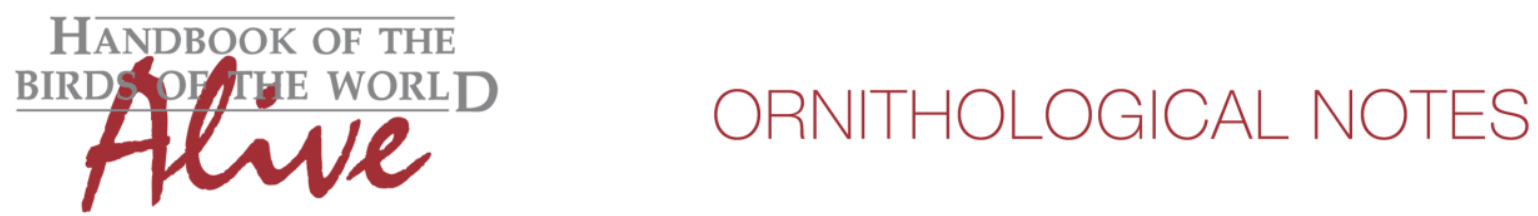

\title{
Notes on the vocalizations of Narcissus Flycatcher (Ficedula narcissina)
}

Peter Boesman

In the following we briefly analyze and compare voice of the different races of Narcissus

Flycatcher (Ficedula narcissina). We also try to quantify the extent of any vocal differences using the criteria proposed by Tobias et al. (2010), as a support for taxonomic review.

We have made use of sound recordings available on-line from Xeno Canto (XC).

Voice was analyzed in detail by Dong et al. (2015). The main discriminating sound parameters are said to be duration of song strophe, max./min. freq. and freq. range (bandwidth). As average values and standard deviation are given (here reproduced: Table 3):

Table 3. Song measurements in the Ficedula narcissina-Ficedula zanthopygia complex (mean \pm 1 SD).

\begin{tabular}{lcccc}
\hline & $F$. zanthopygia & $F, n$. narcissina & F. n. owstoni & \multicolumn{1}{c}{$\boldsymbol{F}$. elisae } \\
\hline DS & $0.83 \pm 0.04$ & $3.49 \pm 1.94$ & $0.71 \pm 0.11$ & $2.99 \pm 0.93$ \\
$F_{\max }$ & $4.42 \pm 0.13$ & $5.20 \pm 0.45$ & $4.53 \pm 0.43$ & $7.70 \pm 0.60$ \\
$F_{\min }$ & $1.84 \pm 0.06$ & $1.70 \pm 0.34$ & $2.29 \pm 0.27$ & $1.45 \pm 0.10$ \\
$F_{\mathrm{r}}$ & $2.58 \pm 0.13$ & $3.49 \pm 0.38$ & $2.24 \pm 0.31$ & $6.25 \pm 0.63$ \\
\hline
\end{tabular}

DS, duration of strophe $(\mathrm{s}) ; F_{\max }$, maximum frequency $(\mathrm{kHz}) ; F_{\min }$, minimum frequency $(\mathrm{kHz}) ; F_{\mathrm{n}}$, frequency range $(\mathrm{kHz})$.

we can calculate effect size:

$\begin{array}{llll} & \begin{array}{l}\text { narcissana } \\ \text { vs owstoni }\end{array} & \begin{array}{l}\text { narcissana } \\ \text { vs elisae }\end{array} & \begin{array}{l}\text { owstoni } \\ \text { vs elisae }\end{array} \\ \text { Duration song strophe } & 2.02 & 0.32 & 3.44 \\ \text { Max. freq. } & 1.52 & 4.71 & 6.07 \\ \text { Min. feq. } & 1.92 & 1.00 & 4.12 \\ \text { Freq. range } & 3.60 & 5.30 & 8.08\end{array}$

resulting in 'Tobias scores':

$\begin{array}{llll} & \text { vs owstoni } & \text { vs elisae } & \text { vs elisae } \\ \text { Duration song strophe } & 2 & 1 & 2 \\ \text { Max. freq. } & 1 & 2 & 3 \\ \text { Min. feq. } & 1 & 1 & 2 \\ \text { Freq. range } & 2 & 3 & 3\end{array}$

(We haven't included zantophygia in the calculations, already treated as a species in HBW)

We can thus conclude that when applying Tobias criteria, total vocal scores between the 3 taxa range from 4 to 6 (assuming that bandwidth and max. freq. are independent parameters).

owstoni has the shortest song phrases and the narrowest freq. range

elisae has the highest max. freq. and largest freq. range

nominate is somewhat closer to elisae, but has a narrower freq. range and slightly lower max.

freq. 
HANDBOOK OF THE

BIRDPPIVIE WORLD ORNITHOLOGICAL NOTES

The authors did not include the parameter 'number of notes in a song phrase', which is much lower in owstoni (score 3 vs other races).

This vocal analysis was based on songs of 14 individuals of race narcissus. Given the very high variability in song, this is quite a low number.

We have recently added some 20 recordings of race narcissus including song of at least 7 individuals, ranging from $\mathrm{S}$ to $\mathrm{N}$ Japan (see $\mathrm{XC}$ ).

Without having done precise measurements, it would seem that these recordings greatly enlarge the min. freq. range, and to a lesser extent freq. range and max. freq.

The above-mentioned scores should thus be seen as really maximum scores.

The overall conclusions however remain valid.

Some examples per race, illustrated with sonograms: narcissana
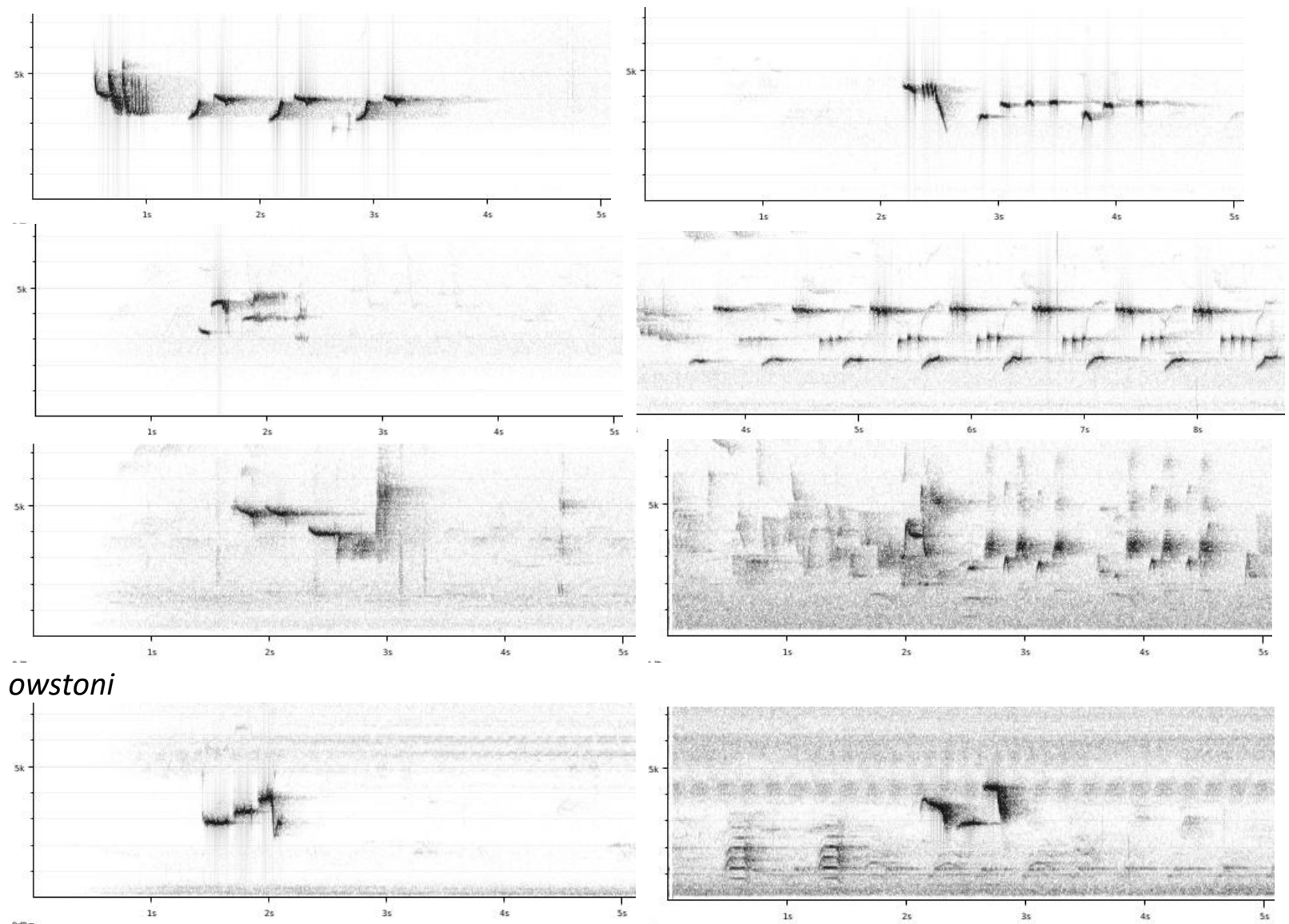

elisa
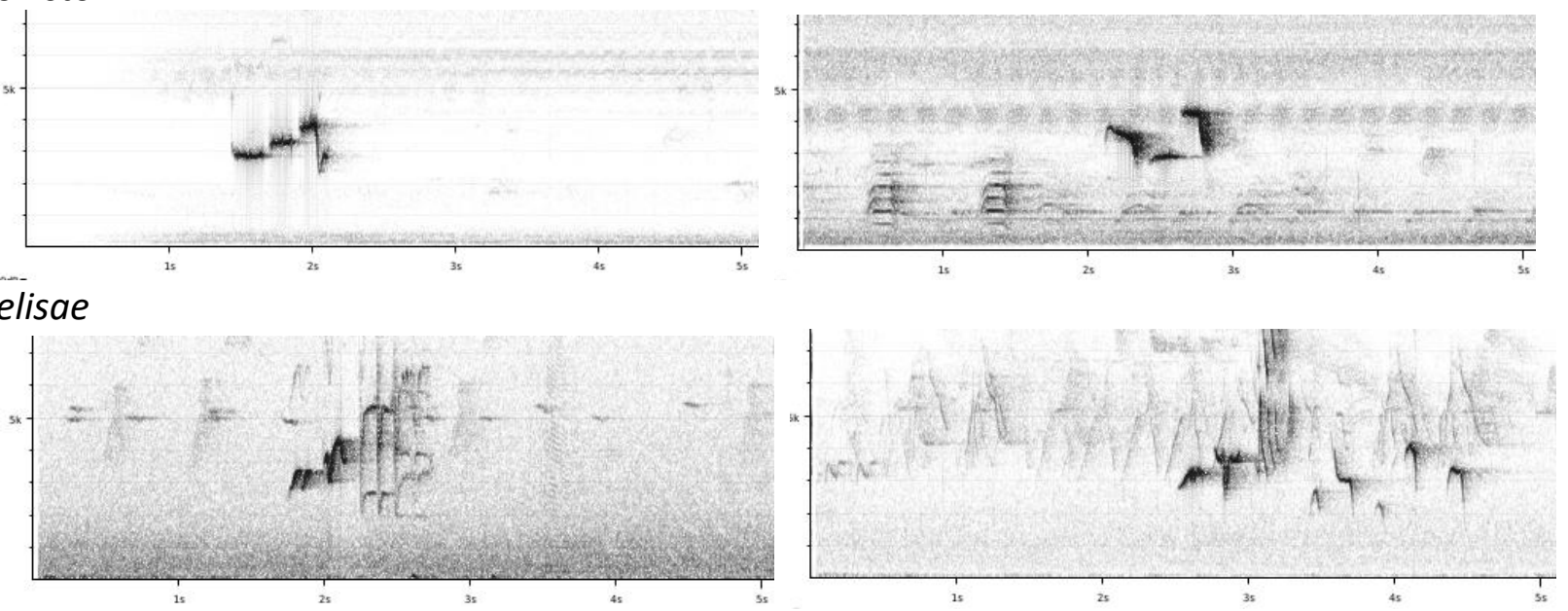

2 

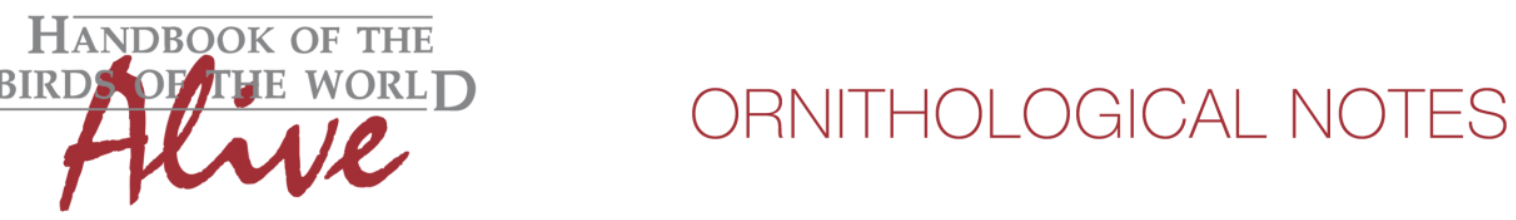

This note was finalized on 11th May 2016, using sound recordings available on-line at that moment. We would like to thank in particular the sound recordists who placed their recordings for this species on XC: Desmond Allen, Per Alström, Peter Boesman, Jim Holmes, Frank Lambert, Urban Olsson, Mathias Ritschard, Brendan Sloan, Anon Torimi, George Wagner

\section{References}

Dong, L., Wei, M., Alström, P., Huang, X., Olsson, U., Shigeta, Y., Zhang, Y. \& Zheng, G. (2015). Taxonomy of the Narcissus Flycatcher Ficedula narcissina complex: an integrative approach using morphological, bioacoustic and multilocus DNA data. Ibis 157(2): 312-325.

Tobias, J.A., Seddon, N., Spottiswoode, C.N., Pilgrim, J.D., Fishpool, L.D.C. \& Collar, N.J. (2010). Quantitative criteria for species delimitation. Ibis 152(4): 724-746.

\section{Recommended citation}

Boesman, P. (2016). Notes on the vocalizations of Narcissus Flycatcher (Ficedula narcissina). HBW Alive Ornithological Note 329. In: Handbook of the Birds of the World Alive. Lynx Edicions, Barcelona. (retrieved from http://www.hbw.com/node/1252680 on 22 October 2016). 